\title{
Spring bloom succession, grazing impact and herbivore selectivity of ciliate communities in response to winter warming
}

\author{
N. Aberle $\cdot$ K. Lengfellner $\cdot$ U. Sommer
}

Received: 10 February 2006/ Accepted: 9 August 2006

(C) Springer-Verlag 2006

\begin{abstract}
This study aimed at simulating different degrees of winter warming and at assessing its potential effects on ciliate succession and grazing-related patterns. By using indoor mesocosms filled with unfiltered water from Kiel Bight, natural light and four different temperature regimes, phytoplankton spring blooms were induced and the thermal responses of ciliates were quantified. Two distinct ciliate assemblages, a pre-spring and a spring bloom assemblage, could be detected, while their formation was strongly temperature-dependent. Both assemblages were dominated by Strobilidiids; the pre-spring bloom phase was dominated by the small Strobilidiids Lohmaniella oviformis, and the spring bloom was mainly dominated by large Strobilidiids of the genus Strobilidium. The numerical response of ciliates to increasing food concentrations showed a strong acceleration by temperature. Grazing rates of ciliates and copepods were low during the prespring bloom period and high during the bloom ranging from $0.06\left(\Delta 0^{\circ} \mathrm{C}\right)$ to $0.23 \mathrm{day}^{-1}\left(\Delta 4^{\circ} \mathrm{C}\right)$ for ciliates and $0.09\left(\Delta 0^{\circ} \mathrm{C}\right)$ to $1.62 \mathrm{day}^{-1}\left(\Delta 4^{\circ} \mathrm{C}\right)$ for copepods. During the spring bloom ciliates and copepods showed a strong dietary overlap characterized by a wide food spectrum consisting mainly of Chrysochromulina sp., diatom chains and large, single-celled diatoms.
\end{abstract}

Communicated by Roland Brandl.

Priority programme of the German Research Foundationcontribution 4 .

N. Aberle $(\bowtie) \cdot K$. Lengfellner $\cdot$ U. Sommer

IFM-GEOMAR Leibniz Institute of Marine Sciences,

Düsternbrooker Weg 20, 24116 Kiel, Germany

e-mail: naberle@awi-bremerhaven.de
Keywords Microzooplankton - Baltic Sea spring assemblages - Climate change $\cdot$ Plankton mesocosms Global change

\section{Introduction}

Recent studies have shown that climate change strongly influences aquatic communities on the global scale, thus affecting plankton community dynamics leading to regime shifts in the pelagic realm (Beaugrand et al. 2003; McGowan et al. 2003; Greve et al. 2004; Smol et al. 2005). The re-structuring of planktonic systems in response to global warming is one of the major topics in aquatic ecology at present, and there is much debate on the degree of climatic sensitivity of different trophic components (Walther et al. 2002; Hays et al. 2005; Winder and Schindler 2004). In this context, the microzooplankton is an important player as it is considered as the trophic link between the microbial components and higher trophic levels (Johansson et al. 2004; Sommer et al. 2005). Microzooplankton communities are generally regarded as being major consumers of planktonic primary producers, consuming as much as $60-70 \%$ depending on the species composition and the nutrient status of the environment (Landry and Calbet 2004). While traditional food-web models proposed a direct transfer of energy from phytoplankton to mesozooplankton (Cushing 1989), it has only relatively recently become clear that microzooplankton, and especially ciliates, can contribute considerably to the diets of mesozooplankters (Kleppel 1993). The trophic pathway through microzooplankton thus enables a rapid regeneration 
and/or cycling of nutrients (Irigoien et al. 2005; Calbet and Saiz 2005).

In temperate regions, the seasonal succession of plankton is initiated by a spring bloom of phytoplankton. These blooms are triggered predominantly by increasing light and nutrient availabilities (Greve and Reiners 1995; Sommer 1996) and only indirectly by temperature, e.g., via the effects of thermal stratification and/or cloud cover (Sverdrup 1953; Wiltshire and Manly 2004). Growth and grazing of consumers are, however, strongly influenced by thermal conditions. The metabolism and production of zooplankton is known to increase with increasing temperature (Montagnes and Lessard 1999), and at identical food supply, zooplankton population growth will become faster the warmer the spring temperatures are. As hypothesized by Scheffer et al. (2001), such changes in thermal conditions might alter the timing and the extent of the clear-water phase with substantial consequences for phytoplankton biomass peaks in spring as well as for top-down effects on phytoplankton. Consequently, a rise in sea surface temperature will not only affect distinct trophic levels per se, but also the complex nature of trophodynamic interactions, leading to a temporal asynchrony between predators and their prey (match-mismatch hypothesis; Cushing 1975).

Especially in spring, ciliates are considered as key components of planktonic communities as they show a more rapid metabolism and production per unit weight than mesozooplankton (Fenchel and Finlay 1983; Mueller and Geller 1993; Montagnes and Lessard 1999), thus enabling an instantaneous response to increasing food availability during the phytoplankton spring bloom (Johansson et al. 2004). In addition, as over-wintering mesozooplankton populations are usually low at this time of the year, ciliates are still released from grazing pressure through secondary consumers. Previous studies on grazing preferences of ciliates have stressed the overall importance of ciliates as primary consumers in general and also the major role of certain ciliate species in consuming spring phytoplankton communities, especially in the Baltic Sea (Smetacek 1981; Kivi et al. 1993; Leppaenen and Bruun 1988; Johansson et al. 2004).

For north-central Europe, a pronounced winter warming is predicted (IPCC 2001), which could lead to an increase in the annual mean surface temperatures of $3-5^{\circ} \mathrm{C}$ and an increase in winter temperatures of even 5-10 ${ }^{\circ} \mathrm{C}$ (prediction for $2070-2100$ as compared to the reference period 1960-1990). In the light of these predictions, the motivation of this study was to address the question how the spring succession of plankton will change in response to the forecast climate changes at the beginning of the growth season. For this purpose, four different temperature regimes $(+0,+2,+4$, and $+6^{\circ} \mathrm{C}$ ) were chosen. It is hypothesized that increased temperatures will accelerate heterotrophic processes more strongly than light limited phytoplankton growth. As a consequence, this could lead to asynchronies between predators and their prey ("match-mismatch" hypothesis, Cushing 1975) with significant impacts on ecosystem stability.

In this study, we hypothesized that the different temperature regimes will lead to (1) an acceleration of ciliate growth by temperature, (2) higher amplitudes of ciliate biomass with increasing temperature, (3) an earlier initiation of the clear-water phase, (4) postponed and attenuated succession patterns of ciliate communities at lower temperature, and (5) higher grazing rates with increasing temperatures.

\section{Materials and methods}

\section{Experimental set-up}

The experimental set-up consisted of eight mesocosms in temperature-controlled culture rooms with an experimental period lasting from 4 February to 4 May 2005. The mesocosms consisted of a two-chamber system, with a 1,400-1 plankton chamber and a smaller (300-1) benthos chamber, which served as a source for meroplanktonic larvae and of planktonic organisms germinating from benthic resting stages. Plankton was gently stirred by a propeller. There was a continuous, but small exchange (on average ca. 601 day $^{-1}$ ) of the water between both chambers. Temperature and light regimes in both chambers were identical. The experiment was run as an almost closed system. Only the sample volume was replaced by unfiltered water from the Kiel Fjord. A detailed description of the set-up is given in Sommer et al. (2006). In this study, only samples from the plankton chamber are considered.

Four temperature regimes $\left(+0,+2,+4\right.$, and $+6^{\circ} \mathrm{C}$; temperature difference to a baseline seasonal trend, each in duplicate) were established whereas temperature differences between treatments were $2^{\circ} \mathrm{C}$ until the end of February, and the differences were reduced by $0.25^{\circ} \mathrm{C}$ per month thereafter to mimic less pronounced warming later in the year. The $+0^{\circ} \mathrm{C}$ temperature regime was defined as the decadal average 1993-2002 in the Kiel Bight. The light set-up allowed simulating daily triangular light curves with natural day lengths and preserved integrated light intensities; the timing of sunrise and sundown and the maximum light intensity was supplied daily by a computer program (GHL, Prometeus). Light 
attenuation by the cloud cover was superimposed by a randomized cloud cover generator (Profilux II) assuming an average $80 \%$ cloud cover and a mean light intensity $\left(I_{\text {mix }}\right)$ of a $12-\mathrm{m}$ mixed water column with a vertical attenuation coefficient of $0.6 \mathrm{~m}^{-1}$.

The mesocosms were filled with unfiltered water pumped directly from Kiel Bight in front of the IFMGEOMAR pier (6-m water depth) containing the over-wintering populations of phytoplankton, bacteria and microzooplankton. The more sensitive copepod fraction was added from net catches at natural densities (ca. 16 ind $\mathrm{l}^{-1}$ ) because a stocking of undamaged copepods via pumping could not be assured. For details on stocking the mesocosms with organisms and water exchange, see Sommer et al. (2006).

The in vivo fluorescence as a proxy for phytoplankton biomass was detected on workdays by a Turner Fluorometer 10 AU (Turner Designs, Sunnyvale, CA).

\section{Ciliate sampling}

Samples for ciliates were taken three times per week (Monday, Wednesday, and Friday) by sampling seawater from the mixed water column $(30-\mathrm{cm}$ water depth) with a bucket. A total of $250 \mathrm{ml}$ of the sampled seawater was transferred to brown-glass bottles and fixed with Lugol's iodine (1\% final concentration). A low concentration of Lugol's fixative was used in order to avoid a strong shrinkage of cells (see Setaelae and Kivi 2003). Of each sample, $100 \mathrm{ml}$ was transferred to sedimentation chambers, and ciliates were counted by the inverted microscope method (Utermöhl 1958) at a 200× magnification with a Zeiss Axiovert 200. The whole area of the bottom plate was counted for each sample in order to guarantee a comparability of the counting both at periods of high and low ciliate abundance. The ciliates were identified to the lowest possible taxonomic level (some to the species, others to the genus level) according to Kahl (1932), Foissner et al. (1991, 1992, 1994, 1995) and Strüder-Kypke et al. (2002). Uncertain species were given scientific names after the ciliate species they most resembled (cf. indicates uncertain species names). Note that identification of ciliates in Lugol-preserved samples is in most cases uncertain below the genus level. A more precise determination of Lugol's fixed ciliates to the species level requires the use of specific staining methods and a laborious working-up of the samples. The present study was geared to determining morphospecies and changes in ciliate assemblages, and thus such complexity was not required. This is an accepted way to proceed in the literature (see: Setaelae and Kivi 2003; Gaedke and Wickham 2004; Johansson et al. 2004; Sommer et al. 2005; Berninger and Wickham 2005).

For biovolume calculations, geometric proxies were used according to Hillebrand et al. (1999), and ciliate carbon biomass was calculated using the conversion factors given in Putt and Stoecker (1989). In addition, ciliates were grouped into size categories (small: $<25 \mu \mathrm{m}$; medium: $25-50 \mu \mathrm{m}$; large: $>50 \mu \mathrm{m}$ ).

\section{Grazing experiments}

The grazing experiments lasted for $48 \mathrm{~h}$ and were run twice during the whole experimental period (pre-spring bloom grazing experiment: 09-11 March 2005; spring bloom grazing experiment: 21-23 March 2005). A modified version of Landry and Hassett's (1982) dilution technique was used by replacing glass bottles by dialysis tubes of 300-ml volume (Medicell International Ltd., London) and a molecular weight cut-off of 12-14,000 Da (Wiltshire and Lampert 1999; Sommer et al. 2005). The dialysis membrane enabled the free exchange of nutrients between the interior of the bags and the surrounding water. At each temperature regime, one of the mesocosms was stocked with five dilution grades $(20,40,60,80$, and $100 \%$ of unfiltered water), each receiving different mixtures of unfiltered water with the original plankton suspension (mesozooplankton removed by a $125-\mu \mathrm{m}$ mesh) and $0.2 \mu \mathrm{m}$ of filtered water from the mesocosms. The dialysis bags were placed close to the water surface within the mesocosms. For starting-point and end-point samples, $250 \mathrm{ml}$ of water from the dilutions were transferred to brown glass bottles, preserved with Lugol's iodine solution, and $100 \mathrm{ml}$ of each sample was transferred to sedimentation chambers. For the determination of the ciliates' biomass and taxonomic composition, see the details in the section Ciliate sampling. Phytoplankton $>5 \mu \mathrm{m}$ were counted under the inverted microscope and distinguished to the species or genus level. One hundred individuals per taxonomic unit were counted, which gave $95 \%$ confidence limits of $\pm 20 \%$; however, this standard could not be attained for rare species. Small phytoplankton and bacteria were counted by a flow cytometer (FACScalibur ${ }^{\mathrm{TM}}$, Becton Dickinson) and distinguished by the size and fluorescence of the pigments chlorophyll $a$, allophycocyanin and phycoerythrin. Three flow-cytometer categories of phytoplankton were matched to flagellate species identified microscopically: (1) Chrysochromulina, (2) autotrophic nanoflagellates (Plagioselmis sp., Teleaulax sp.) and (3) autotrophic picoplankton (APP). 
Calculation of growth and grazing rates

Net growth rates $\left(r ;\right.$ day $\left.^{-1}\right)$ in the mesocosms and the dialysis bags were calculated as:

$r=\left(\ln N_{1}-\ln N_{2}\right) /\left(t_{2}-t_{1}\right)$.

Grazing rates by microzooplankton $\left(\gamma_{\text {micro }}\right)$ in the mesocosms were calculated according to the method of Landry and Hassett (1982), where $\gamma_{\text {micro }}$ can be calculated by a linear regression of $r$ in the dialysis bags on the share of unfiltered water $(x)$ :

$r=\mu-\gamma_{\text {micro }} \times x$

$\left(\gamma_{\text {micro, }}\right.$ grazing mortality from slope; $\mu$, growth rate from $y$-axis intercept; $x$, dilution factor).

Grazing rates by copepods $\left(\gamma_{\text {cop }}\right)$ were calculated as the difference between net growth rates calculated from Eq. 2 for $x=1\left(r_{1}\right)$ and $r$ in the mesocosms:

$\gamma_{\text {cop }}=r_{1}-r_{\text {meso }}$

This assumes that phytoplankton in the mesocosms was only reduced by microzooplankton and copepod grazing and that other factors affecting phytoplankton mortality where equal between mesocosms and dialysis bags.

Total grazing rates of ciliates and copepods $\left(\gamma_{\text {tot }}\right)$ were calculated from the sum of products of specific grazing rates for each algal species $\left(\gamma_{a, b, c, . . .}\right)$ and the ratios between the carbon biomass of each algae $\left(B_{a, b, c, \ldots}\right)$ and the total algal carbon biomass $\left(B_{\text {tot }}\right)$ $\left(a, b, c, \ldots=B_{a, b, c, \ldots} / B_{\mathrm{tot}}\right)$.

$\gamma_{\mathrm{tot}}=\gamma_{a} a+\gamma_{b} b+\gamma_{c} c+\cdots$

\section{Statistical analysis}

To test for significant effects of the different temperature regimes $\left(+0,+2,+4\right.$, and $+6^{\circ} \mathrm{C}$, each in duplicate) on the response variables of ciliates (timing of the ciliate biomass maxima, diversity), statistical tests using regression analysis were conducted. As independent factor $\Delta T\left({ }^{\circ} \mathrm{C}\right)$ and as dependent factors Julian day and $H^{\prime}$ were chosen using STATISTICA 6.0. Diversity was calculated using PRIMER 5.2 (2001 Primer-E Ltd.). Diversity was measured by the Shannon-Wiener function $\left(H^{\prime} ; \log _{\mathrm{e}}\right)$ (Shannon and Weaver 1963).

\section{Results}

Ciliate biomass

At the beginning of the experiment, ciliate carbon biomass increased in all mesocosms, leading to a prespring bloom ciliate maximum (PSCM) (Fig. 1a-d). During this period, carbon biomass increased more rapidly in the warmest mesocosms $\left(\Delta 6^{\circ} \mathrm{C}\right.$; PSCM = Julian day $47+54)$, reaching values of 4.3 and $2.6 \mu \mathrm{g} \mathrm{C}^{-1}$, respectively (Fig. 1a). At the coldest temperature, ciliate biomass peaked on day 61 and 68 , reaching maxima of $3.5 \mu \mathrm{g} \mathrm{C} \mathrm{l}^{-1}$ (Fig. 1d). The timing of the pre-spring bloom ciliate maximum $\left(t_{\mathrm{pscm}}\right)$ showed a significant acceleration of 2.1 days per ${ }^{\circ} \mathrm{C}$ (Table 1).

After the PSCM, a decline in ciliate biomass was detected, followed by a transition phase characterized by fluctuating biomass. With the onset of the phytoplankton spring bloom, a significant increase in ciliate biomass was detected in all mesocosms (Fig. 1a-d). A more rapid increase was found at higher temperatures as the timing of the spring bloom ciliate maximum $\left(t_{\mathrm{scm}}\right)$ was accelerated by 2.0 days per ${ }^{\circ} \mathrm{C}$ (Table 1$)$. The spring bloom ciliate maxima were: $17.3 \mu \mathrm{g} \mathrm{C} \mathrm{l}^{-1}$ $\left(\Delta 6^{\circ} \mathrm{C}, \quad\right.$ Fig. 1a $), \quad 18.0 \mu \mathrm{g} \mathrm{C}^{-1} \quad\left(\Delta 4^{\circ} \mathrm{C}, \quad\right.$ Fig. $\left.1 \mathrm{~b}\right)$, $16.0 \mu \mathrm{g} \mathrm{C}^{-1}\left(\Delta 2^{\circ} \mathrm{C}\right.$, Fig. 1c) and $6.3 \mu \mathrm{g} \mathrm{C}^{-1}\left(\Delta 0^{\circ} \mathrm{C}\right.$, Fig. 1d).

The biomass peaks were followed by a sharp decline within a few days, and minimum abundances were observed between Julian days 108-124.

Ciliate community structure

\section{Size structure}

During the pre-spring bloom period, the ciliate community was dominated by small ciliates $(<25 \mu \mathrm{m})$, comprising a maximum of $74-98 \%$ of the total ciliate community (Fig. 2a-d). The proportions of large ciliates $(>50 \mu \mathrm{m})$ were much smaller $(4-23 \%)$, and medium size fractions $(25-50 \mu \mathrm{m})$ were almost absent. With the onset of the phytoplankton spring bloom, the size structure changed considerably as a shift in size fractions towards larger ciliate taxa was observed. Especially in the warmest mesocosms $\left(\Delta 6, \Delta 4^{\circ} \mathrm{C}\right)$, a dominance of large species $(>50 \mu \mathrm{m})$ contributing up to $75 \%$ to the total ciliate community was found (Fig. 2a, b), whereas in the coldest mesocosms $(\Delta 2$, $\left.\Delta 0^{\circ} \mathrm{C}\right)$, similar proportions of medium- and large-sized taxa occurred (Fig. 2c, d). 

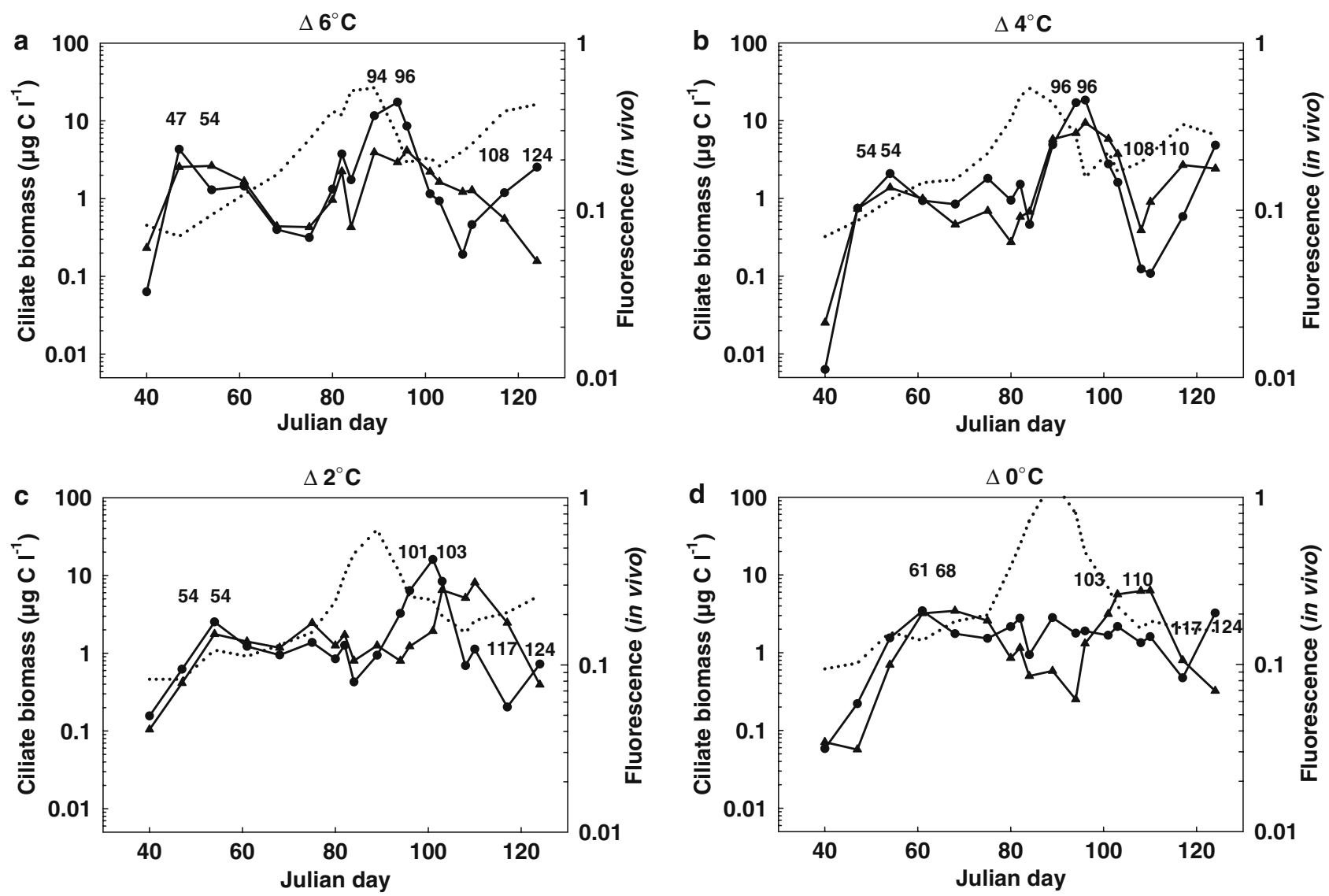

Fig. 1 Ciliate biomass ( $\mu \mathrm{g} \mathrm{C}^{-1}$ ) (solid lines) and in vivo fluorescence of phytoplankton (dashed line) in the mesocosms. Numbers indicate the day of the pre-spring bloom maximum, the spring bloom maximum and the biomass minimum after spring

bloom; treatments: a $\Delta 6^{\circ} \mathrm{C}$; b $\Delta 4^{\circ} \mathrm{C}$; c $\Delta 2^{\circ} \mathrm{C}$; d $\Delta 0^{\circ} \mathrm{C}$. Symbols indicate the duplicate mesocosms: triangles (uneven mesocosm numbers), circles (even mesocosm numbers)

Table 1 Regressions of ciliate response variables on treatment intensity $\left(\Delta T\right.$ in $\left.{ }^{\circ} \mathrm{C}\right)$

\begin{tabular}{lllll}
\hline Variable & Unit & Equation & $r^{2}$ & $P$ \\
\hline Time of pre-spring bloom ciliate maximum & Julian day & $t_{\text {pscm }}=62.1-2.1 \Delta T$ & 0.65 & 0.015 \\
Time of spring-bloom ciliate maximum & Julian day & $t_{\mathrm{scm}}=106-2.0 \Delta T$ & 0.81 & 0.0024 \\
Ciliate diversity & $H^{\prime}$ & $d=0.68+0.03 \Delta T$ & 0.32 & 0.14 \\
Time of clear-water phase & Julian day & $t_{\mathrm{cwp}}=119-4.25 \Delta T$ & 0.80 & 0.0025
\end{tabular}

\section{Taxonomic composition}

At all temperature regimes the pre-spring bloom period was dominated by the Strobilidiid Lohmaniella oviformis showing biomass peaks ranging from $1.4 \mu \mathrm{g} \mathrm{C}^{-1}\left(\Delta 4^{\circ} \mathrm{C}\right.$; Fig. 3b) to $3.2 \mu \mathrm{g} \mathrm{C}^{-1}\left(\Delta 0^{\circ} \mathrm{C}\right.$; Fig. 3d). The dominance of $L$. oviformis persisted during the transition phase, while Scuticociliates made

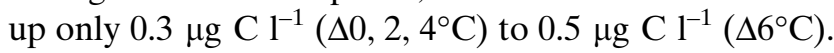
The proportions of Strombidiids and other Strobilidiids were low prior to the spring bloom and increased rapidly shortly after the phytoplankton biomass started to increase. At warmer temperatures, the period of the spring bloom ciliate maximum was initiated by the appearance of Balanion comatum. This small Prostome occurred at high abundances at the very early start of the bloom, and its biomass reached values between $0.8 \mu \mathrm{g} \mathrm{C}^{-1}\left(\Delta 2^{\circ} \mathrm{C}\right)$ and $1.7 \mu \mathrm{g} \mathrm{C}^{-1}\left(\Delta 4^{\circ} \mathrm{C}\right)$ (Fig. 3a-c). Immediately after the B. comatum peak, the ciliates shifted towards a Strobilidiid-dominated community comprising of large ciliates, mostly of the Strobilidium species. Again, the peaks were most pronounced at elevated temperatures where the community was dominated by the species Strobilidium 

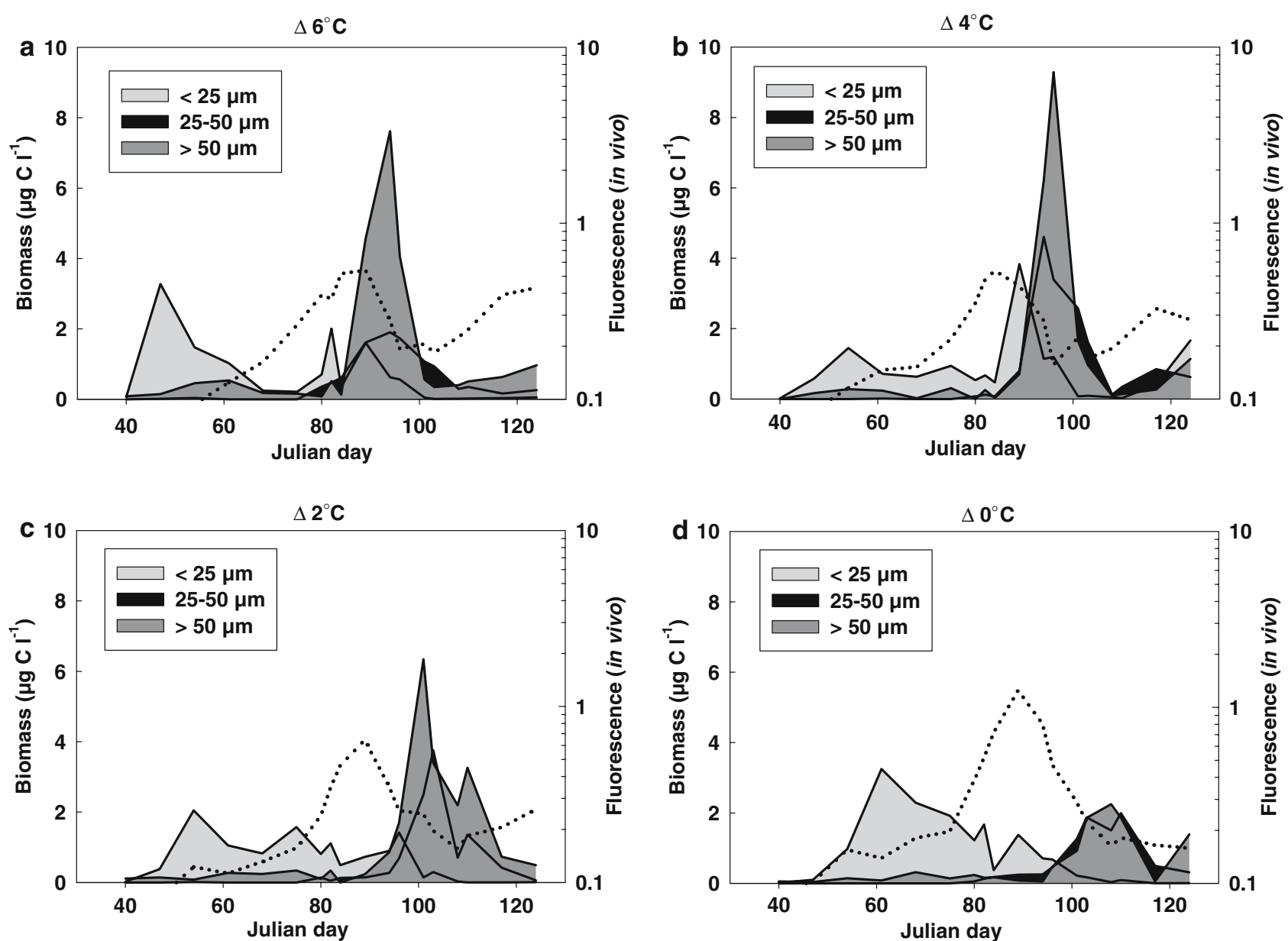

Fig. 2 Size class composition of ciliate biomass ( $\mu \mathrm{g} \mathrm{C} \mathrm{l}^{-1} ;<25 \mu \mathrm{m}, 25-50 \mu \mathrm{m},>50 \mu \mathrm{m}$ ) as the mean of duplicate mesocosms and in vivo fluorescence (dashed line) in the mesocosms; treatments: a $\Delta 6^{\circ} \mathrm{C} ; \mathbf{b} \Delta 4^{\circ} \mathrm{C} ; \mathbf{c} \Delta 2^{\circ} \mathrm{C} ; \mathbf{d ~} \Delta 0^{\circ} \mathrm{C}$

caudatum, reaching biomass maxima of up to $8.8 \mu \mathrm{g} \mathrm{C} 1^{-1}\left(\Delta 4^{\circ} \mathrm{C}\right)$. In addition, Acineta and Euplotes species occurred, although at low numbers. Heterotrophic dinoflagellates were of no importance in our mesocosms. At the coldest temperature $\left(\Delta 0^{\circ} \mathrm{C}\right)$, the spring bloom ciliate community was also dominated by $S$. caudatum (Fig. 3d). However, compared to the warmer mesocosms, this species showed a much lower biomass of $2.2 \mu \mathrm{g} \mathrm{Cl}^{-1}$ and other species, e.g., the Strombidium conicum and Strobilidium longipes appeared in low numbers.

\section{Diversity}

The diversity $\left(H^{\prime}\right)$ in the mesocosms showed higher values at elevated temperatures with a mean $H^{\prime}$ between $0.9\left(\Delta 6^{\circ} \mathrm{C}\right)$ and $0.7\left(\Delta 0^{\circ} \mathrm{C}\right)$ (Fig. 4). Nevertheless, the correlation was weak, and the temperature dependence not significant (Table 1). The main reason for the insignificance of this correlation was the low diversity in mesocosm $4\left(\Delta 4^{\circ} \mathrm{C}\right)$, where especially $B$. comatum occurred at much lower abundances compared to its parallel mesocosm 3 .

\section{Ciliate grazing}

\section{Total grazing rates}

During the pre-spring bloom period, total ciliate grazing rates showed a negative response to warming (Fig. 5a). Values at different temperatures ranged from $0.02\left(7^{\circ} \mathrm{C}\right)$ to $0.11 \mathrm{day}^{-1}\left(3^{\circ} \mathrm{C}\right)$. With the onset of the bloom, grazing rates showed a slight increase, with temperature and values ranging from $0.06\left(4^{\circ} \mathrm{C}\right)$ to $0.23 \mathrm{day}^{-1}\left(8^{\circ} \mathrm{C}\right)$.

During the pre-spring bloom period, copepods showed low grazing rates $\left(0.003-0.14\right.$ day $^{-1}$ at 3 and $6^{\circ} \mathrm{C}$ ), and no clear trend in relation to temperature was 

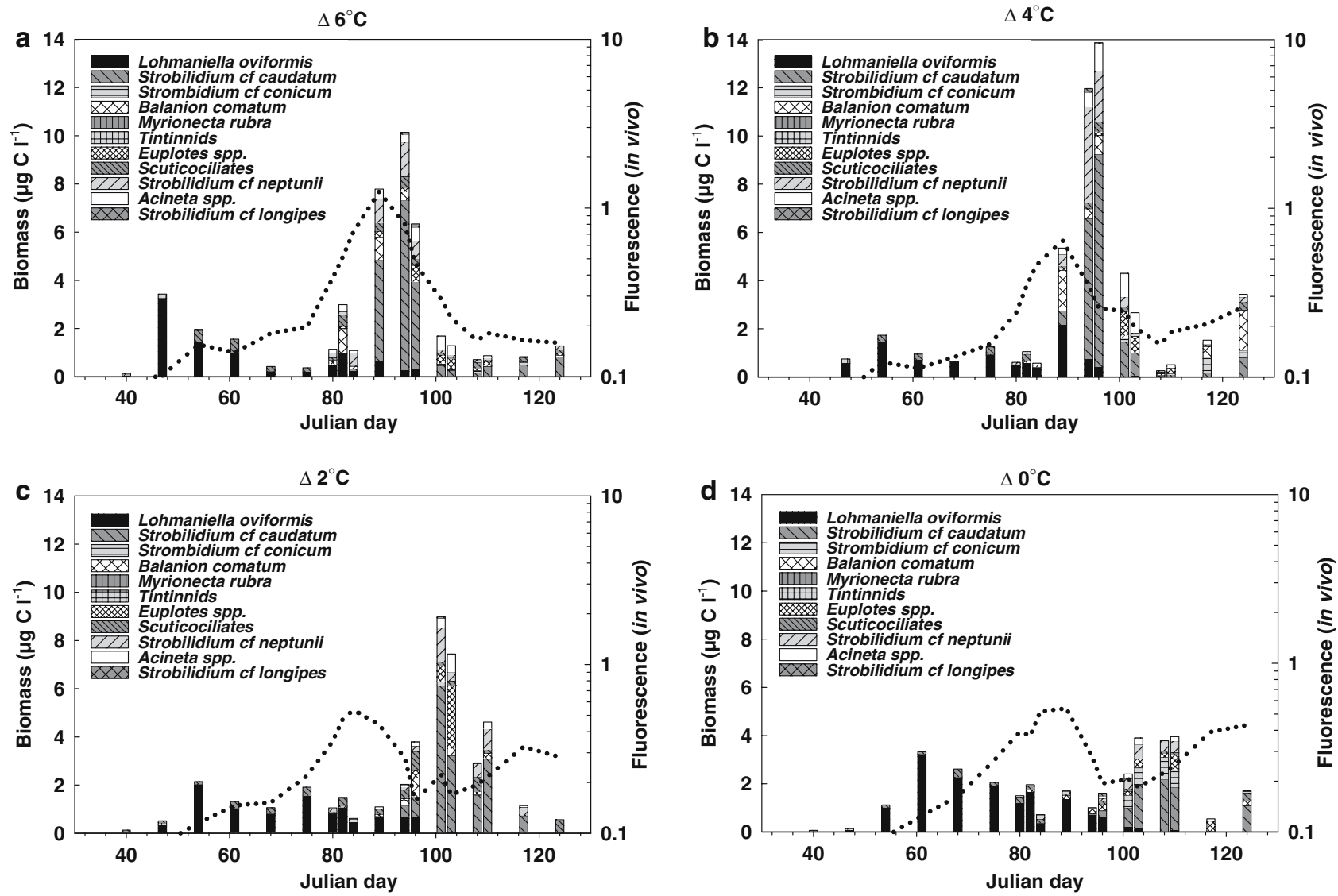

Fig. 3 Taxonomic composition of ciliates biomass $\left(\mu \mathrm{g} \mathrm{C} \mathrm{l}^{-1}\right)$ as the mean of duplicate mesocosms and in vivo fluorescence (dashed line) in the mesocosms; treatments: a $\Delta 6^{\circ} \mathrm{C} ; \mathbf{b} \Delta 4^{\circ} \mathrm{C} ; \mathbf{c} \Delta 2^{\circ} \mathrm{C} ; \mathbf{d} \Delta 0^{\circ} \mathrm{C}$. cf. indicates uncertain species names

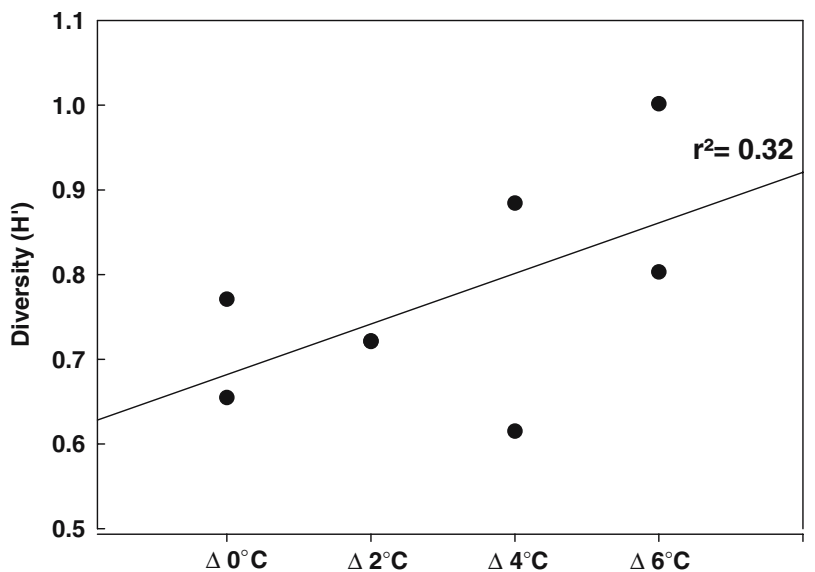

Fig. 4 Diversity index $\left(H^{\prime}\right)$ of the ciliate communities in the mesocosms at $\Delta 0, \Delta 2, \Delta 4$, and $\Delta 6^{\circ} \mathrm{C}$. Details of the linear regression are shown in the graph

found (Fig. 5b). At the beginning of the spring bloom, grazing rates of copepods increased, showing values of $0.09-1.6$ day $^{-1}$ at 4 and $8^{\circ} \mathrm{C}$. A trend of higher grazing rates of copepods at higher temperatures was observed.

\section{Grazing selectivity}

In general, no temperature-related effects on grazer selectivity were detected, and a strong overlap between the food sources used by ciliates and copepods was observed.

Due to the low grazing rates of ciliates and copepods during the pre-spring bloom period, the consideration of species-specific grazing by zooplankton was restricted to only a few phytoplankton taxa. For ciliates, grazing on Chrysochromulina sp. was detected in all treatments prior to the bloom, whereas diatoms (Skeletonema costatum and Thalassionema nitzschioides) were grazed in three out of four treatments (Fig. 6a). Data on bacteria grazing for this time frame are unfortunately not available since an analytical error occurred while measuring samples. Grazing of diatoms by ciliates was confirmed by microscopic observations showing diatoms within the ciliates' food vacuoles. Grazing upon autotrophic nanoflagellates and autotrophic picoplankton (APP) was negligible. At the beginning of the spring bloom ciliates showed high grazing rates when preying upon bacteria and diatoms 

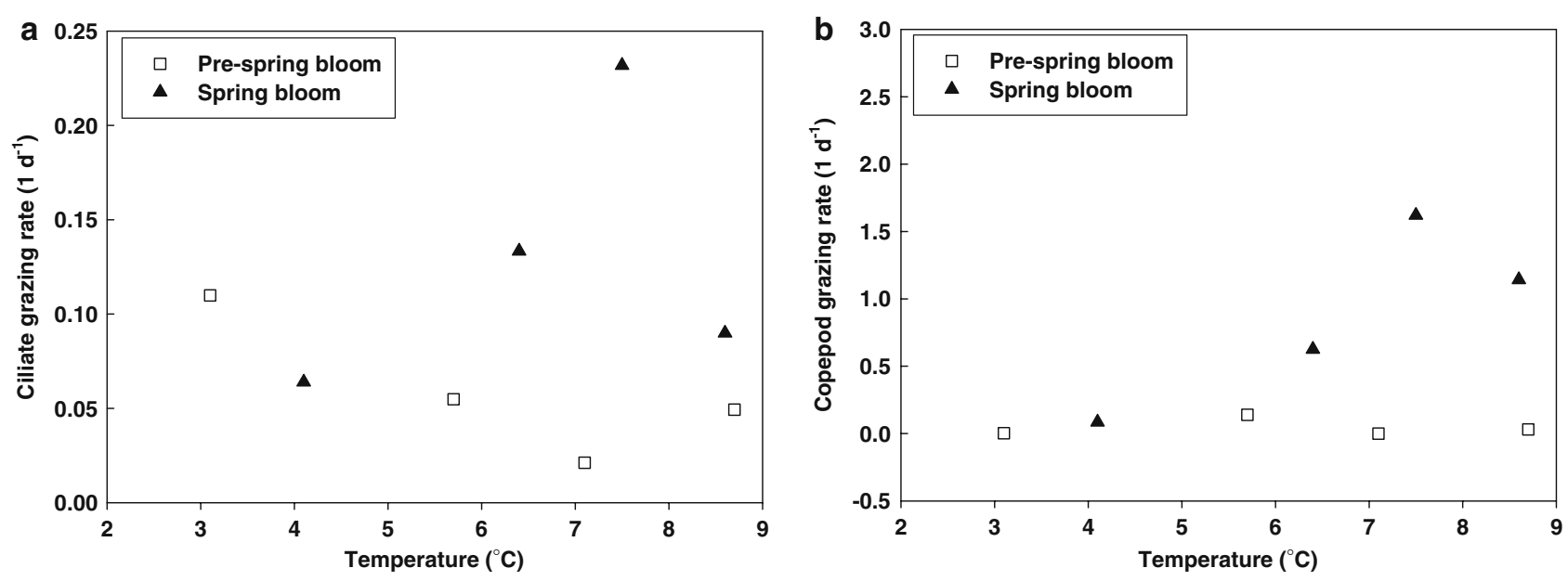

Fig. 5 Total grazing rates $\left(1\right.$ day $\left.^{-1}\right)$ of ciliates (a) and of copepods (b) during the pre-spring bloom (open squares) and the spring bloom (closed circles) period in the mesocosms at actual temperatures $\left({ }^{\circ} \mathrm{C}\right)$

Fig. 6 Grazing rates $\left(1\right.$ day $\left.^{-1}\right)$ of ciliates $(\mathbf{a})$ and of copepods (b) during the pre-spring bloom period at $\triangle 0, \Delta 2, \Delta 4$, and $\Delta 6^{\circ} \mathrm{C} ; A P P$, autotrophic picoplankton; Nanoflag, nanoflagellates; Chrysochrom,

Chrysochromulina sp.; Tnem, Thalassionema nitzschioides; Skel, Skeletonema costatum

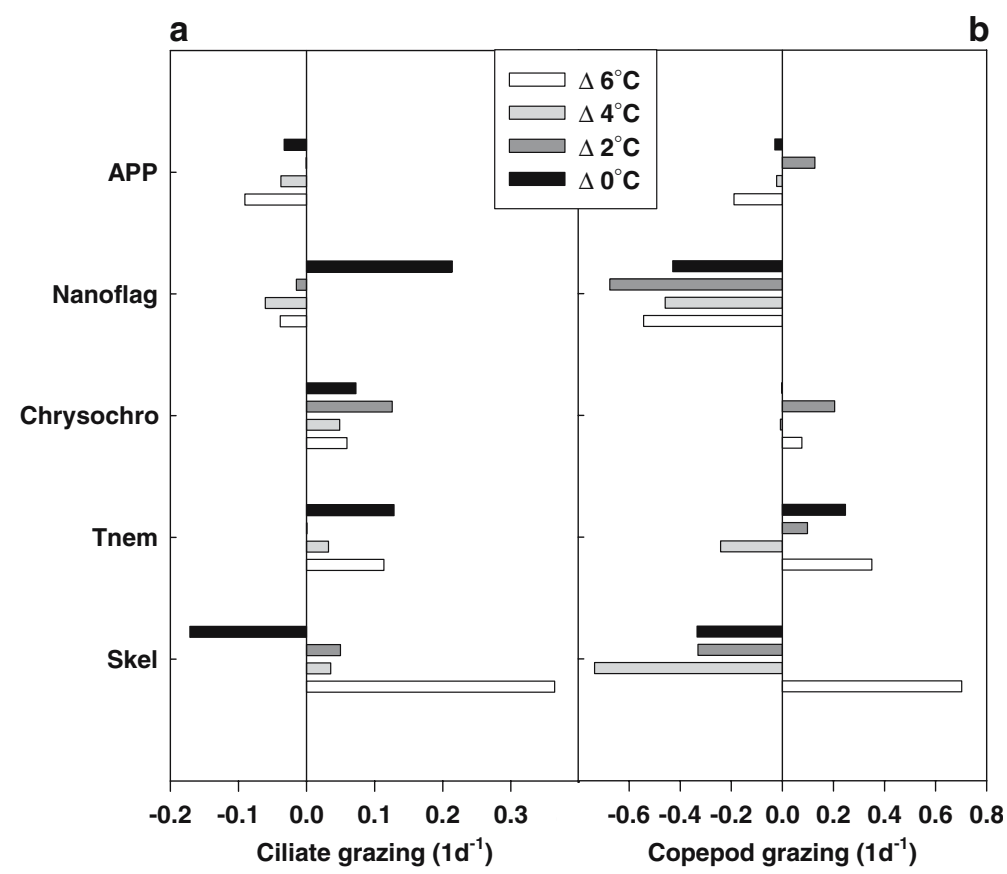

(Nitzschia acicularis, Navicula sp., Tabularia fasciculata), while Chrysochromulina sp. and the small diatom S. costatum were grazed at considerable amounts in the majority of treatments (Fig. 7a). Nanoflagellates and APP were of minor importance as prey for ciliates.

Copepods showed only a weak grazing during the pre-spring bloom period (Fig. 6b). Except for the $\Delta 4^{\circ} \mathrm{C}$ treatment, the diatom $T$. nitzschioides was grazed to moderate degrees at all temperatures, whereas Chrysochromulina sp. and S. costatum were consumed only in some treatments. During the spring bloom the copepods showed a high consumption of several phytoplankton species no matter at which temperature
(N. acicularis, Navicula sp., Chrysochromulina sp. and S. costatum) (Fig. 7b). However, the diatom T. fasciculata was consumed only at elevated temperatures.

\section{Discussion}

The major aim of this study was to elucidate the impact of warming on ciliate communities during the winterspring transition in the Baltic Sea. The hypotheses that higher temperatures will lead to accelerated growth and grazing rates, higher biomass and different succession patterns of ciliates were tested. Furthermore, 
Fig. 7 Grazing rates $\left(1\right.$ day $\left.^{-1}\right)$ of ciliates (a) and of copepods (b) during the spring bloom period at $\Delta 0, \Delta 2, \Delta 4$, and $\Delta 6^{\circ} \mathrm{C} ; A P P$, autotrophic picoplankton; Chrysochrom, Chrysochromulina sp.; Nanoflag, nanoflagellates; Niac, Nitzschia acicularis; Navi, Navicula sp.; Tabu, Tabularia fasciculata; Skel, Skeletonema costatum

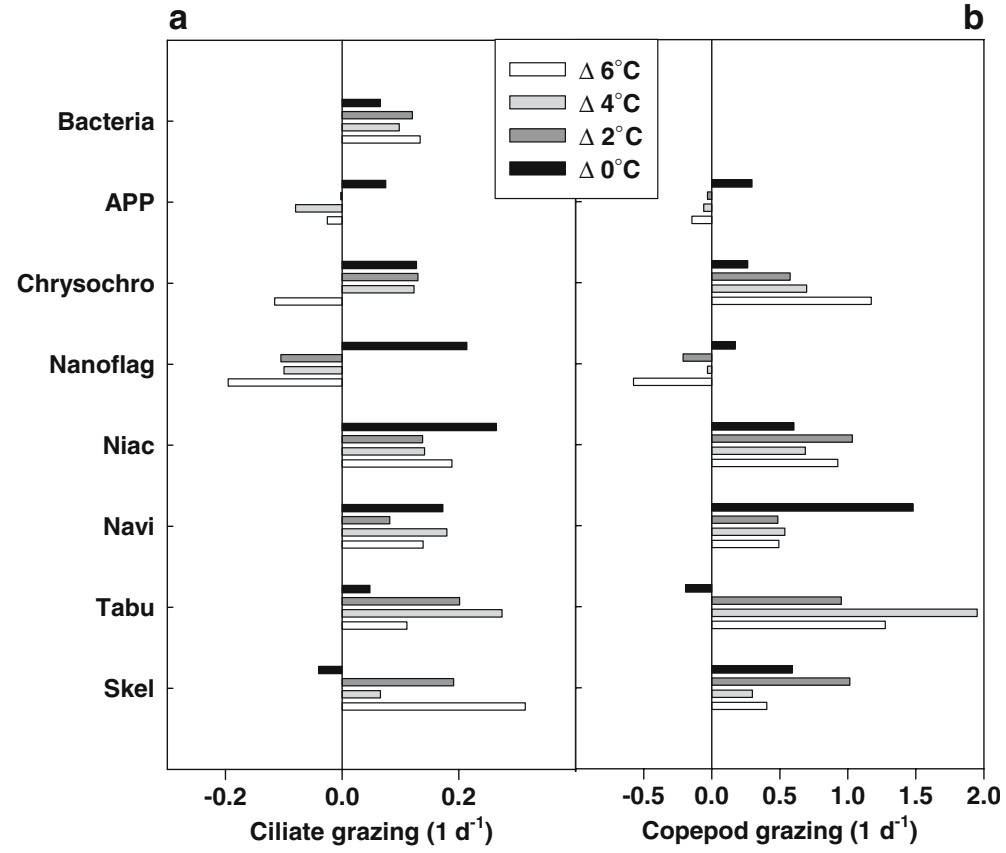

the coupling between phytoplankton, microzooplankton and mesozooplankton during spring succession, the ciliates' community dynamics and their trophic role were central focuses of the present study.

\section{Ciliate biomass}

The factors temperature and food supply are regarded as major triggers of short-term ciliate biomass maxima, especially during spring succession (Smetacek 1981; Johansson et al. 2004), and ciliate populations are known to be especially affected by the thermal conditions of a system (Weisse and Montagnes 1998; Montagnes and Lessard 1999; Johansson et al. 2004). Ciliates usually respond numerically and rapidly to increasing food availabilities, and their growth rates are considered to follow a linear rather than an exponential trend in response to temperature (Montagnes and Lessard 1999; Tillmann 2004). These general patterns of ciliate growth are supported by the findings from our mesocosm experiment.

In the light of a winter warming scenario for northern central Europe (IPCC 2001), with predicted increases in the sea surface temperature of $5-10^{\circ} \mathrm{C}$ during winter, an earlier onset of consumer pressure during the winter-spring transition is assumed since zooplankton growth is known to be highly affected by temperature, while light limited phytoplankton growth is not. Such a scenario could lead to temporal asynchronies between autotrophic production and heterotrophic consumption with substantial consequences for the match or mismatch of planktonic organisms. During our experiment an acceleration of ciliate growth and higher biomass maxima at elevated temperatures were observed. Thus, our first two hypotheses that the ciliates' growth will be accelerated by temperature and that an enhanced growth of ciliates with increasing temperature will occur were confirmed.

Another good indication of climate-induced changes in the planktonic realm is the shift in timing of specific events during plankton succession, e.g., the timing of the clear-water phase. The initiation of the clear-water phase is, in general, attributed to heavy grazing, mainly by mesozooplankton, and several studies were able to link meteorological phenomena like the NAO index (North Atlantic Oscillation) to the timing of the clearwater phase (Straile and Adrian 2000; Scheffer et al. 2001). However, as already pointed out by Tirok and Gaedke (2006), the role of smaller zooplankton fractions, e.g., ciliates, on the timing of the clear-water phase have been mostly neglected, although their temperature response is well-documented in the literature (Mueller and Geller 1993, Montagnes and Weisse 2000; Weisse et al. 2001). In our experiment, we observed an earlier initiation of the clear-water phase at elevated temperatures and a shift in timing by 4 days per ${ }^{\circ} \mathrm{C}$ (Table 1$)$. In addition, the timing of the ciliates' biomass maxima was accelerated by 2 days per ${ }^{\circ} \mathrm{C}$, and thus, it seems likely that the rapid and more intense response of ciliate communities at elevated temperatures could be responsible for the earlier initiation of the clear-water phase in the warm set-ups. 
Consequently, our hypothesis that an earlier initiation of the clear-water phase at elevated temperatures will occur could be confirmed. Similar to our experimental study, field data from Tirok and Gaedke (2006) point at a high grazing pressure by microzooplankton at times when mesozooplankton abundances are low. In their study, the clear-water phase was, however, only initiated when mesozooplankton populations grazing on large-sized algae developed. The discrepancies between their field data and the results from our mesocosm experiment might arise from the fact that a high proportion of ciliates in our mesocosms showed a preference for large diatom cells (see Discussion section on "Ciliate grazing and feeding preferences"). This enabled a predominately ciliate-induced initiation of the clear-water phase under warmer climatic conditions. Our results show that this small but important aspect - that, in response to warming, ciliates have a high potential to alter such distinct events as the timing of the clear-water phase- requires further attention.

However, blooming events of microzooplankton are not only bottom-up regulated. Several studies emphasized the role of ciliates as food source for mesozooplankton organisms (Stoecker and Capuzzo 1990; Nejstgaard et al. 2001; Granéli and Turner 2002). As in the field (Behrends 1996), copepod abundance showed a rapid decline with the duration of our experiment. The decline in predator abundance obviously released ciliates from grazing pressure through copepods in our mesocosms, a typical feature of reduced top-down control of ciliates in planktonic systems (Kivi et al. 1996; Granéli and Turner 2002; Calbet and Saiz 2005).

The degrees at which external forcing factors are responsible for the match or mismatch between organisms in the field usually remain uncertain. Our indoor mesocosm experiment provided new insights into the coupling between bottom-up and top-down control mechanisms in the light of warming trends and should thus stress the need for experimental approaches to meet the complexity of climate change research issues.

\section{Ciliate community composition}

Species composition, diversity and the peak amplitudes of single ciliate species were strongly affected by temperature in our study. An analysis of long-term plankton data in the North Sea showed similar patterns for mesozooplankton communities as shifts in species composition and increases in diversity were observed (Beaugrand 2004; Hays et al. 2005). However, Irigoien et al. (2004) characterized microzooplankton diversity predominantly as a unimodal function of phytoplankton biomass, and ciliates are known to show a high species specificity regarding food concentrations, feeding preferences and temperature requirements (Mueller and Schlegel 1999; Weisse et al. 2001). Thus, it can be assumed that the combined effect of temperature, food supply and food composition might be responsible for the high diversity in the warmer set-ups.

In this study, the composition of ciliates during winter-spring succession was similar to the one documented by Smetacek (1981) and Johansson et al. (2004) for the Baltic Sea. Peaks of heterotrophic dinoflagellates, as observed by Smetacek (1981) during spring blooms in the Kiel Bight, could not be detected. Compared to ambient temperatures, the amplitudes of peak maxima of individual ciliate species showed a clear positive temperature response as, e.g., the small Strobilidiids $L$. oviformis showed a more rapid population growth in the warmer set-ups during the prespring bloom period. This species is known to occur mainly during winter or early spring when the temperatures and phytoplankton biomass are still relatively low (Johansson et al. 2004). Despite its natural thermal requirements, a strong temperature dependence of L. oviformis populations was detected. A similar trend was observed for the Prostome B. comatum, a species that dominated the ciliate community at the beginning of the spring bloom period and that is a typical representative of Prostomes in the Baltic Sea mainly during spring and summer (Johansson et al. 2004). Prostomes usually reach high biomass levels at intermediate phytoplankton biomass and high growth rates at moderate temperatures (Weisse et al. 2001). In our study, both intermediate food concentrations and increasing temperatures right at the beginning of the bloom seemed to favor the occurrence of this small Prostome species.

As proposed by Montagnes et al. (1988), clear spring assemblages with large-sized ciliates preying upon large phytoplankton size fractions are found, while summer, autumn and winter assemblages are usually dominated by small ciliates consuming small prey, e.g., bacterioplankton and flagellates (Kivi and Setaelae 1995; Setaelae and Kivi 2003). Our findings of composition changes and shifts towards larger ciliate size fractions during spring support Montagnes and coworkers' general concept on ciliate seasonal succession, a pattern which is additionally confirmed by field observations during spring succession in the Baltic Sea (Smetacek 1981; Johansson et al. 2004).

Nevertheless, the composition and succession patterns of ciliates in our indoor mesocosms were considerably affected by temperature. As hypothesized initially, we observed postponed and attenuated suc- 
cession patterns of ciliate communities at lower temperatures; under elevated temperature regimes, large spring forms of the genera Strobilidium spp. and Strombidium spp. $(>50 \mu \mathrm{m})$ increased rapidly and strongly when food concentrations increased, while their occurrence was delayed in the colder set-ups and their abundance remained low. A strong temperature response of the Strobilidium and Strombidium species has also been reported by Montagnes (1996), and thus, it can be speculated that an earlier and a more intense peak of large ciliate fractions could alter the timing and the duration of blooms. In the light of a winter warming scenario, the observed thermal sensitivity of large ciliate size fractions could have far-reaching consequences for the spring formation of phytoplankton blooms and the synchrony between planktonic organisms.

Ciliate grazing and feeding preferences

Numerous studies have emphasized the overall importance of micrograzers as dominant consumers of phytoplankton in oligotrophic and eutrophic oceans (Sherr et al. 1992). Traditionally, ciliates were considered as major grazers of microalgae, preying mainly upon nanoplankton size fractions (Jonsson 1986; Kivi and Setaelae 1995; Granéli and Turner 2002; Sommer et al. 2005; Berninger and Wickham 2005), whereas large phytoplankton size fractions like, e.g., diatoms are usually considered as the preferred food item of copepods (Kivi et al. 1996; Granéli and Turner 2002; Sommer et al. 2005). In addition, recent studies also point to the ciliates' importance as bacterivores and to their role as a trophic link between the microbial components in the food web and higher trophic levels (Posch et al. 1999; Simek et al. 2000). Several studies, however, emphasized that the potential food spectrum of ciliates is much larger than commonly believed, since, e.g., large-sized microzooplankton is not restricted to pico- and nanoplankton grazing (Smetacek 1981; Johansson et al. 2004; Tillmann 2004). This is especially true for non-loricate ciliates, which are known for their potential to capture and handle larger food particles with their feeding apparatus and to adapt their shape to that of the ingested particle, thus enabling the ingestion of cells that are as large as or even larger than their own size (Kahl 1932; Smetacek 1981; Montagnes et al. 1988; Jakobsen and Hansen 1997).

In our study, the transition phase was characterized by a low phytoplankton biomass dominated mainly by nanoflagellates in the elevated temperature regimes and diatoms in the $+0^{\circ}$ treatments, declining copepod abundances and a L. oviformis biomass that fluctuated. L. oviformis is considered as a selective feeder preying mainly upon bacterioplankton, heterotrophic nanoflagellates and small phytoplankton fractions and an optimum prey size of approximately $15 \%$ of their body length and prey items ranging from 2 to $15 \mu \mathrm{m}$ (Jonsson 1986; Christaki et al. 1998). With its spherical diameter of $20 \mu \mathrm{m}, L$. oviformis might thus have most likely consumed prey items in the size range of bacterio- and nanoplankton. Unfortunately, data on bacteria and heterotrophic nanoflagellates (HNF) grazing during the pre-bloom period were not available; however, grazing on autotrophic picoplankton (APP) and nanoflagellates by ciliates could be ruled out. A consumption of bacterial and HNF fractions by $L$. oviformis seems thus most plausible. With the onset of the spring bloom, L. oviformis was displaced by B. comatum, and since data from the spring bloom period showed high grazing rates of ciliates preying upon bacteria, this might indicate a bacterivore feeding habit of B. comatum. Although this is in contrast to observations of Balanion spp. showing a preference for small cryptophytes with an optimal prey size of $8 \mu \mathrm{m}$ (Jakobsen and Hansen 1997; Mueller et al. 1991; Weisse and Mueller 1998), a preference of B. comatum for picoplankton fractions seems likely due to its small size. Similar assumptions were drawn by Mueller (1989) on the potential prey items of a small Prostome in Lake Constance. In this context it can be speculated that, despite an overlap of trophic niches, both species, the cold-adapted $L$. oviformis and the warm-adapted $B$. comatum, are released from feeding competition due to their contrasting thermal requirements and their shifted occurrence during season.

In addition, a strong grazing pressure of ciliates on large phytoplankton size fractions was observed. Compared to the ciliates' body size (mainly $>50 \mu \mathrm{m}$ ), large diatoms in the order of 30-180 $\mu \mathrm{m}$ (Nitzschia acecularis, Navicula sp. and T. fasciculata) seem to be exceptionally large prey items. However, this is a pattern commonly observed during phytoplankton blooms as, e.g., large Strobilidiid and Strombidiid ciliates have been shown to prey upon large diatoms or dinoflagellate species that are as large as or even larger than their own size (Kahl 1932; Smetacek 1981; Gifford 1985; Johansson et al. 2004). Our data on the grazing rates of large ciliate taxa support the findings of Strom et al. (2001) proposing that especially in highly productive, coastal areas, microzooplankton is one of the major heterotrophic components that directly consumes large-sized phytoplankton species, contributing to significant losses and a restructuring in phytoplankton biomass (Strom et al. 2001). Diatoms, 
however, do not necessarily provide good food for microzooplankton, even if they are abundant, as some species are known for their grazing resistance. In this context, Irigoien et al. (2005) recently posed the hypothesis that phytoplankton blooms are a 'loophole in microzooplankton grazing' as blooming species are those that are capable of avoiding grazing by using special predation avoidance mechanisms (e.g., larger size, colony structure, and toxic components). In our mesocosm study, the bloom-forming diatom species were those that were consumed most by the zooplankton community, and a bloom formation of inedible phytoplankton could not be observed. However, predation avoidance mechanisms are often species-specific, and the degree varies in relation to biotic and abiotic conditions. The development of such 'loophole-like' bloom patterns can thus not be generalized. A good example is the consumption of Chrysochromulina spp. both by copepods and ciliates in our study. Some species of this genus are assumed to inhibit feeding by consumers due to chemical defence, especially during blooming events (Nielsen et al. 1990; John et al. 2002). In our mesocosms, a distinct bloom of Chrysochromulina spp. did not develop, and the grazing rates indicate that the species present in our study were a suitable food source for ciliates and copepods.

In our study, no clear temperature dependence of grazing was detected during the pre-spring bloom period, while during the spring bloom period, grazing rates were altered by temperature. Due to the contrasting results, the hypothesis that different grazing patterns and accelerated grazing rates might occur at higher temperatures was thus only confirmed to a limited extent. Multiple regression analyses on feeding rates of mesozooplankton published by Peters and Downing (1984) showed much clearer positive trends in response to temperature. Their findings are based on an extensive literature survey and the general statistical model aimed at indicating the extent of agreement among existing studies. Our small-scale approach using dilution experiments was, however, not powerful enough to evolve a clear trend for temperature-dependent grazing rates.

Grazing rates were at the upper end for copepods and at the lower end for ciliates when compared to a late summer situations in Norway (Nejstgaard et al. 2001; Sommer et al. 2005). However, it must be taken into account that during our experiment the cells grazed by ciliates were comprised mainly of large diatom cells with a much higher total biomass when compared to grazing rates that were calculated from nanoflagellate grazing in other mesocosm studies.
In our study, we found a strong dietary overlap in the food spectrum of ciliates and copepods as both groups showed a clear preference for the chains of $S$. costatum, large, single-celled diatoms, and Chrysochromulina sp. The chain-forming diatom S. costatum is known to be a suitable food source, especially for naupli and adult copepods (Olsson et al. 1992; Nejstgaard et al. 2001; Granéli and Turner 2002). Similar to our study, the results of Nejstgaard et al. (2001) also gave some indication for ciliate grazing on S. costatum.

In conclusion, the data presented here showed a clear temperature response of ciliate communities and their dynamics during winter-spring transition. Due to an acceleration of growth, high amplitudes of ciliate biomass and alterations of ciliate composition at elevated temperatures, our study points at potential asynchronies during the spring succession of plankton in the light of a winter warming scenario. At times when mesozooplankton grazing is still low, warming trends could open a loophole, especially for large-sized ciliate species, to evolve rapidly during spring bloom formation. The ability of large-sized ciliates to prey efficiently upon large phytoplankton fractions points at their potential to suppress phytoplankton blooms and furthermore to an enhanced resource competition between the heterotrophic components of the plankton due to a dietary overlap between ciliates and copepods.

Acknowledgments We would like to thank Thomas Hansen, Sandra Schröder and Christine Rautenstrauch for the maintenance of the mesocosms and for their technical support. The participants of the Kiel Plankton Mesocosm Cluster are thanked for the joint experimental activities. We thank Karen Wiltshire and three anonymous reviewers for the valuable and constructive comments on an earlier version of the manuscript. This study was part of the project SO 145/23-1 within the DFG priority program 1162 AQUASHIFT, and we are grateful for the funding. This study complies with the current German law.

\section{References}

Beaugrand G (2004) Monitoring marine plankton ecosystems. 1: description of an ecosystem approach based on plankton indicators. Mar Ecol Prog Ser 269:69-81

Beaugrand G, Brander KM, Lindley JA, Souissi S, Reid PC (2003) Plankton effect on cod recruitment in the North Sea. Nature 426:661-664

Behrends G (1996) Long-term investigation of seasonal mesozooplankton dynamics in Kiel Bight. In: Proceedings of the 13th Symposium of the Baltic Marine Biologists, pp 93-96

Berninger UG, Wickham S (2005) Resonse of microbial food web to manipulation of nutrients and grazers in the oligotrophic Gulf of Aqaba and northern Red Sea. Mar Biol 147:1017-1032

Calbet A, Saiz E (2005) The ciliate-copepod link in marine ecosystems. Aquat Microb Ecol 38:157-167 
Christaki U, Dolan JR, Pelegri S, Rassoulzadegan F (1998) Consumption of picoplankton-size particles by marine ciliates: effects of physiological state of the ciliate and particle quality. Limnol Oceanogr 43:458-464

Cushing DH (1975) Marine ecology and fisheries. Cambridge University Press, London, p 292

Cushing DH (1989) A difference in structure between ecosystems in strongly stratified waters and in those that are only weakly stratified. J Plankton Res 11:1-13

Fenchel T, Finlay BJ (1983) Respiration rates in heterotrophic, free-living protozoa. Microb Ecol 9:99-122

Foissner W, Berger H, Kohmann F (1991, 1992, 1994, 1995) Taxonomische und ökologische Revision der Ciliaten des Saprobiensystems Band I-IV, Informationsberichte Bayerisches Landesamt für Wasserwirtschaft, München

Gaedke U, Wickham SA (2004) Ciliate dynamics in response to changing biotic and abiotic conditions in a large, deep lake (Lake Constance). Aquat Microb Ecol 34:247-261

Gifford DJ (1985) Laboratory culture of marine planktonic oligotrichs (Ciliophora, Oligotrichida). Mar Ecol Prog Ser 23:257-267

Granéli E, Turner JT (2002) Top-down regulation in ctenophorecopepod-ciliate-diatom-phytoflagellate communities in coastal waters: a mesocosm study. Mar Ecol Prog Ser 239:57-68

Greve W, Reiners F (1995) Biocoenotic process patterns in the German Bight. Olsen and Olsen, Fredensborg, pp 67-72

Greve W, Reiners F, Nast J, Hoffmann S (2004) Helgoland Roads meso- and macrozooplankton time-series 1974-2004: lessons from 30 years of single spot, high frequency sampling at the only off-shore island in the North Sea. Helgol Mar Res 58:274-288

Hays GC, Richardson AJ, Robinson C (2005) Climate change and marine plankton. Trends Ecol Evol 20:337-344

Hillebrand H, Duerselen C-D, Kirschtel D, Pollingher U, Zohary T (1999) Biovolume calculation for pelagic and benthic microalgae. J Phycol 35:403-424

IPCC (2001) Impacts, adaptations and vulnerability (UNEP and WHO). Climate Change 2001

Irigoien X, Huisman J, Harris RP (2004) Global biodiversity patterns of marine phytoplankton and zooplankton. Nature 429:863-867

Irigoien X, Flynn KJ, Harris RP (2005) Phytoplankton blooms: a 'loophole' in microzooplankton grazing impact? J Plankton Res 27:313-321

Jakobsen HH, Hansen PJ (1997) Prey size selection, grazing and growth response of the small heterotrophic dinoflagellate Gymnodinium sp. and the ciliate Balanion comatum-a comparative study. Mar Ecol Prog Ser 158:75-86

Johansson M, Gorokhova E, Larsson U (2004) Annual variability in ciliate community structure, potential prey and predators in the open northern Baltic Sea proper. J Plankton Res 26:67-80

John U, Tillmann U, Medlin LK (2002) A comparative approach to study inhibition of grazing and lipid composition of a toxic and non-toxic clone of Chrysochromulina polyepsis (Prymnesiophyceae). Harmful Algae 1:45-57

Jonsson PR (1986) Particle size selection, feeding rates and growth dynamics of marine planktonic oligotrichous ciliates (Ciliophora: Oligotrichina). Mar Ecol Prog Ser 33:265-277

Kahl A (1932) Urtiere oder Protozoa I. Wimpertiere oder Ciliata (Infusoria). In: Dahl F (ed) Tierwelt Deutschlands und der angrenzenden Meeresteile 18:1-886

Kivi K, Setaelae O (1995) Simultaneous measurement of food particle selection and clearance rates of planktonic oligotrich ciliates (Ciliophora: Oligotrichina). Mar Ecol Prog Ser 119:1-3

Kivi K, Kaitala S, Kuosa H, Kuparinen J, Leskinen E, Lignell R, Marcussen B, Tamminen T (1993) Nutrient limitation and grazing control of the Baltic plankton community during annual succession. Limnol Oceanogr 38:893-905

Kivi K, Kuosa H, Tanskanen S (1996) An experimental study on the role of crustacean and microprotozoan grazers in the planktonic food web. Mar Ecol Prog Ser 136:1-3

Kleppel GS (1993) On the diets of calanoid copepods. Mar Ecol Prog Ser 99:1-2

Landry MR, Calbet A (2004) Microzooplankton production in the oceans. ICES J Mar Sci 61:501-507

Landry MR, Hassett RP (1982) Estimating the grazing impact of marine micro-zooplankton. Mar Biol 67:283-288

Leppaenen JM, Bruun JE (1988) Cycling of organic matter during the vernal growth period in the open northern Baltic proper. 4. Ciliate and mesozooplankton species composition, biomass, food intake, respiration, and production. Finn Mar Res 255:55-78

McGowan JA, Bograd SJ, Lynn RJ, Miller AJ (2003) The biological response to the 1977 regime shift in the California Current. Deep Sea Res Part II 50:2567-2582

Montagnes DJS (1996) Growth responses of planktonic ciliates in the genera Strobilidium and Strombidium. Mar Ecol Prog Ser 130:1-3

Montagnes DJS, Lessard EJ (1999) Population dynamics of the marine planktonic ciliate Strombidinopsis multiauris: its potential to control phytoplankton blooms. Aquat Microb Ecol 20:167-181

Montagnes DJS, Weisse T (2000) Fluctuating temperatures affect growth and production rates of planktonic ciliates. Aquat Microb Ecol 21:97-102

Montagnes DJS, Lynn DH, Roff JC, Taylor WD (1988) The annual cycle of heterotrophic planktonic ciliates in the waters surrounding the Isles of Shoals, Gulf of Maine: an assessment of their trophic role. Mar Biol 99:21-30

Mueller H (1989) The relative importance of different ciliate taxa in the pelagic food web of Lake Constance. Microb Ecol 18:261-273

Mueller H, Geller W (1993) Maximum growth rates of aquatic ciliated protozoa: the dependence on body size and temperature reconsidered. Arch Hydrobiol 126:315-327

Mueller H, Schlegel A (1999) Responses of three freshwater planktonic ciliates with different feeding modes to cryptophyte and diatom prey. Aquat Microb Ecol 17:49-60

Mueller H, Schone A, Pintocoelho RM, Schweizer A, Weisse T (1991) Seasonal succession of ciliates in Lake Constance. Microb Ecol 21:119-138

Nejstgaard JC, Hygum BH, Naustvoll LJ, Bamstedt U (2001) Zooplankton growth, diet and reproductive success compared in simultaneous diatom- and flagellate-microzooplanktondominated plankton blooms. Mar Ecol Prog Ser 221:77-91

Nielsen TG, Kioerboe T, Bjoernsen PK (1990) Effects of a Chrysochromulina polylepis subsurface bloom on the planktonic community. Mar Ecol Prog Ser 62:1-2

Olsson P, Graneli E, Carlsson P, Abreu P (1992) Structuring of a postspring phytoplankton community by manipulation of trophic interactions. J Exp Mar Biol Ecol 158:249-266

Peters HP, Downing JA (1984) Empirical analysis of zooplankton filtering and feeding rates. Limnol Oceanogr 29:763-784

Posch T et al (1999) Predator-induced changes of bacterial sizestructure and productivity studied on an experimental microbial community. Aquat Microb Ecol 18:235-246 
Putt M, Stoecker DK (1989) An experimentally determined carbon: volume ratio for marine "oligotrichous" ciliates from estuarine and coastal waters. Limnol Oceanogr 34:1097-1103

Scheffer M, Straile D, Van Nes EH, Hosper H (2001) Climatic warming causes regime shifts in lake food webs. Limnol Oceanogr 46:1780-1783

Setaelae O, Kivi K (2003) Planktonic ciliates in the Baltic Sea in summer: distribution, species association and estimated grazing impact. Aquat Microb Ecol 32:287-297

Shannon C, Weaver W (1963) The mathematical theory of communication. University of Illinois Press, Urbana

Sherr BF, Sherr EB, McDaniel J (1992) Effect of protistan grazing on the frequency of dividing cells in bacterioplankton assemblages. Appl Environ Microbiol 58:2381-2385

Simek K, Juergens K, Nedoma J, Comerma M, Armengol J (2000) Ecological role and bacterial grazing of Halteria spp.: small freshwater oligotrichs as dominant pelagic ciliate bacterivores. Aquat Microb Ecol 22:43-56

Smetacek V (1981) Annual cycle of protozooplankton in the Kiel Bight. Mar Biol 63:1-11

Smol JP et al (2005) Climate-driven regime shifts in the biological communities of arctic lakes. Proc Natl Acad Sci USA 102:4397-4402

Sommer U (1996) Plankton ecology: the past two decades of progress. Naturwissenschaften 63:293-301

Sommer U, Hansen T, Blum O, Holzner N, Vadstein O, Stibor H (2005) Copepod and microzooplankton grazing in mesocosms fertilised with different Si:N ratios: no overlap between food spectra and Si:N influence on zooplankton trophic level. Oecologia 142:274-283

Sommer U, Aberle N, Engel A, Hansen T, Lengfellner K, Sandow M, Wohlers J, Zoellner E, Riebesell U (2006) An indoor mesocosm system to study the effect of climate change on the late winter and spring succession of Baltic Sea phytoand zooplankton. Oecologia (in press)

Stoecker DK, Capuzzo JM (1990) Predation on protozoa: its importance to zooplankton. J Plankton Res 12:891-908

Straile D, Adrian R (2000) The North Atlantic Oscillation and plankton dynamics in two European lakes-two variations on a general theme. Global Change Biol 6:663-670
Strom SL, Brainard MA, Holmes JL, Olson MB (2001) Phytoplankton blooms are strongly impacted by microzooplankton grazing in coastal North Pacific waters. Mar Biol 138:355-368

Strüder-Kypke MC, Kypke ER, Agatha S, Warwick J, Montagnes DJS (2002) Guide to UK coastal planktonic ciliates (http://www.liv.ac.uk/ciliate/site/index.htm). Copyright (C) 2002 David Montagnes, The University of Liverpool, Port Erin Marine Laboratory, Port Erin, Isle of Man, British Isles

Sverdrup H (1953) On conditions for the vernal blooming of phytoplankton. J Cons Explor Mer 18:287-295

Tillmann U (2004) Interactions between planktonic microalgae and protozoan grazers. J Eukaryot Microbiol 51:156-168

Tirok K, Gaedke U (2006) Spring weather determines the relative importance of ciliates, rotifers and crustaceans for the initiation of the clear-water phase in a large, deep lake. J Plankton Res 28:361-373

Utermöhl H (1958) Zur Vervollkommnung der quantitativen Phytoplankton-Methodik. Mitt Int Ver Limnol 9:1-38

Walther GR et al (2002) Ecological responses to recent climate change. Nature 416:389-395

Weisse T, Montagnes DJS (1998) Effect of temperature on interand intraspecific isolates of Urotricha (Prostomatida, Ciliophora). Aquat Microb Ecol 15:285-291

Weisse T, Mueller H (1998) Planktonic protozoa and the microbial food web in Lake Constance. Arch Hydrobiol 53:223-254

Weisse T, Karstens N, Meyer VCL, Janke L, Lettner S, Teichgraber K (2001) Niche separation in common prostome freshwater ciliates: the effect of food and temperature. Aquat Microb Ecol 26:167-179

Wiltshire KH, Lampert W (1999) Urea excetion by Daphnia: a kairomone for colony formation in Scenedesmus? Limnol Oceanogr 44:1894-1903

Wiltshire KH, Manly BFJ (2004) The warming trend at Helgoland Roads, North Sea: phytoplankton response. Helgol Mar Res 58:269-273

Winder M, Schindler DE (2004) Climate change uncouples trophic interactions in an aquatic ecosystem. Ecology 85:21002106 